\title{
Climate variation and crop production in Georgia, USA, during the twentieth century
}

\author{
Vesselin A. Alexandrov ${ }^{1}$, Gerrit Hoogenboom ${ }^{2, *}$ \\ ${ }^{1}$ National Institute of Meteorology and Hydrology, 1784 Sofia, Bulgaria \\ ${ }^{2}$ Department of Biological and Agricultural Engineering, The University of Georgia, Griffin, Georgia 30223, USA
}

\begin{abstract}
Most climate variability studies have been conducted at a regional level in which it was assumed that the climate was uniform for each individual climatic zone. The objective of this study was to determine climate variability at a local level for the entire state of Georgia during the 20th century. Daily historical weather data for 85 weather stations were analyzed for the period 1901-1997. Annual air temperature for the century showed a statistically significant negative trend. A similar tendency was found for both the warm- and cold-half of the year, as well as the individual winter, spring and summer seasons. Georgia has experienced several drought episodes during the 20th century, especially during the 1930s, 1950s and 1980s. Drought was most severe in 1954 across central and south Georgia, with precipitation less than $35 \%$ of the normal (1961-1990) climatic values. A decrease in precipitation during the warm-half of the year (April-September) from the end of 1970s until present was found. Although there was an increase in summer precipitation from the beginning of the 1980s, the overall trend showed a decrease in summer precipitation. Most El Niño episodes during the cold-half of the year featured an increased frequency of occurrences of above normal precipitation. During the autumn El Niño events, Georgia has tended to be warmer than the normal climatic conditions. However, almost all classified winter El Niños were connected by lower mean air temperature during the winter season. This lower temperature during the winter resulted in an increase in winter wheat yield. Higher air temperatures during the growing season resulted in a shorter growing duration, causing a reduction in yield. The spring and summer crops used in this study were affected by both precipitation deficits and higher air temperatures during the warm-half of the year. Since 1961, maize yield was higher in most years when El Niño events occurred during the warm-half of the year. The statistical linear yield models that were developed in this study can be used for assessments of expected anomalies of mean winter wheat, maize, soybean, peanut and cotton yield in Georgia for a particular year.
\end{abstract}

KEY WORDS: Georgia $\cdot$ Climate variability $\cdot$ El Niño $\cdot$ Crop yield $\cdot$ Statistical models

\section{INTRODUCTION}

The Earth's climate has exhibited marked 'natural' variations and changes, with time scales ranging from millions of years down to 1 or $2 \mathrm{yr}$. Over periods of several years, fluctuations in global surface temperatures of a few tenths of a degree are common. Some of these are related to the El Niño-Southern Oscillation (ENSO)

*Corresponding author. E-mail: gerrit@griffin.peachnet.edu phenomenon, while major volcanic eruptions have also had some impacts. The concentration of greenhouse gases in the atmosphere has continued to increase. This is largely due to human activities, mostly fossil fuel use, land-use change, and agriculture. About $64 \%$ of the warming effect caused by greenhouse gas increases over the last $200 \mathrm{yr}$ is due to carbon dioxide (e.g., Houghton et al. 1996). Global mean surface temperature has increased by between 0.3 and $0.6^{\circ} \mathrm{C}$ since the late 19th century. It is quite possible that this warming suggests a discernible human influence on 
global climate (e.g., Houghton et al. 1996). In recent years, the problem of climate variations, caused by natural processes as well as anthropogenic changes in the atmosphere, has reached worldwide attention by scientists as well as the popular press. The national variations as well as the regional trends of the US climate during the 20th century have been studied extensively (e.g., Karl et al. 1995a-c, Portman \& Gutzler 1996, Michaels et al. 1998, Easterling 1999). Climate variations for some specific US regions have also been investigated (e.g., Stahle \& Cleaveland 1994, Skaggs et al. 1995, Henderson \& Muller 1997, Woodhouse 1997, Cayan et al. 1998, NCDC 1999).

Climate is a primary determinant of agricultural productivity. Any modifications of weather due to the impact of climate variability directly affect crop production (e.g., Thompson 1986, Stooksbury \& Michaels 1994, WMO 1994, Kaufmann \& Snell 1997, Perkey \& Hayes 1998, Rotter et al. 1998, Freckleton et al. 1999, Gadgil et al. 1999). Crop yields are affected by variations in climatic factors such as air temperature and precipitation and the frequency and severity of extreme events such as droughts, floods, hurricanes, windstorms, and hail. During the last few years the influence of climate variability caused by the ENSO phenomenon on agricultural productivity has also received a significant interest by scientists (e.g., Carlson et al. 1996, Singels \& Potgieter 1997, Hansen et al. 1998a-c, Philips et al. 1998, Solow et al. 1998, Mauget \& Upchurch 1999, Todey et al. 1999).

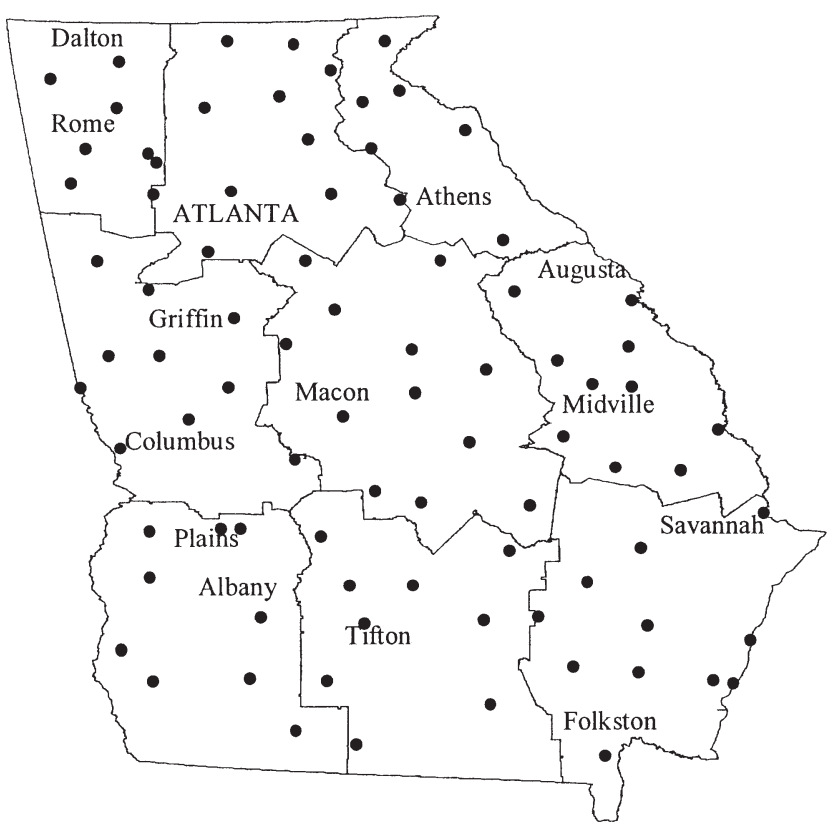

Fig. 1. Spatial distribution of the weather stations used in this study
There is no doubt that the impact of climate variability on agricultural production is important at different levels, including the local, regional, national, and global scale. In the southeastern USA, agriculture is one of the most important economic sectors (Hansen \& Jones 1999). The objective of this study was to investigate climate variations in Georgia during the 20th century and the related yield fluctuations of important agricultural crops, including winter wheat, maize, soybean, peanut, and cotton.

\section{EXPERIMENTAL MATERIALS AND METHODS}

Daily weather information for the 20th century (1901-1997) was gathered for all climatic zones in Georgia. The state is divided into 9 divisions, which are areas of similar climatological characteristics. Daily weather data recorded at 85 weather stations were used; most of the sites are located in remote areas where urbanization did not directly affect the local climate (Fig. 1).

Maximum and minimum air temperature and precipitation data were obtained from EarthInfo Inc. (1997). Missing values were interpolated using available weather information from the nearest neighboring stations. There are 2 limitations related to the weather data used in this study. The number of stations with available weather data varied during the study period that ranged from 1901 to 1997 . Only 8 weather stations were available from the beginning of the century until 1930; the number of stations increased significantly in 1948. Another limitation is that weather data were not tested for homogeneity due to lack of sufficient metadata. Available mean yield data of winter wheat, maize, soybean, peanut and cotton in Georgia during the period 1901-1997 were obtained from a published database, developed by the National Agricultural Statistics Service (NASS 1999).

The Southern Oscillation is a pronounced disturbance of the atmospheric circulation over lower latitudes of the Pacific sector associated with a redistribution of mass during the course of the El Niño warming and La Niña cooling of the Equatorial Pacific. The Southern Oscillation (strength and direction) is measured by a simple index, the Southern Oscillation Index (SOI). The SOI is defined as the normalized pressure difference between Tahiti and Darwin. There are several slight variations in the SOI values calculated at various centers. In this study, the SOI monthly values, provided by the Climate Research Unit, United Kingdom, for the period 1901-1997, were used (CRU 1999). The SOI calculations are based on the method given by Ropelewski \& Jones (1987). Details of the early pressure sources and methods used to compile 
the series from 1896 onwards can be found in Allan et al. (1991) and Können et al. (1998). A negative SOI value is associated with warm El Niño conditions in the eastern Pacific. Different SOI thresholds have been used to identify El Niño events, 2 of them equal to -0.8 or -1.0 (e.g., Kiladis \& van Loon 1988, Carlson et al. 1996, Trenberth 1997, Todey et al. 1999). As the SOI should only be used when monthly means are smoothed (e.g., Trenberth 1997), El Niño event occurrences in this study were classified on an annual and seasonal SOI basis using the -0.8 threshold (Table 1 ).

Obtained time series of air temperature and precipitation anomalies were smoothed by a 5 yr running average. Two non-parametric tests were used to determine the possible existence of statistically significant trends of air temperature and precipitation assuming a $5 \%$ probability level-the Mann-Kendall and Spearman rank statistics (e.g., WMO 1966, 1990).

Since the introduction of statistics, relations between weather and agricultural production and crop yields have been quantified. One of the earliest quantitative studies of the effect of weather on crop yield is by Smith (1914). Usually, simple or multiple regression models are developed to determine which climate terms have the most important impact on agricultural crop yield. These models provide the basis for estimating the regional production for a given set of climatic conditions. Statistical models that determine crop yield from climate variables generally relate historical estimates of yield with climate variables such as precipitation, temperature, and soil moisture (e.g., Katz 1979, Thompson 1986, 1988, Decker \& Achutuni 1988). In this study we also present the relationships that exist between climatic conditions and yield of winter wheat, maize, soybean, peanut, and cotton in Georgia. The statistical crop-weather models were developed with a stepwise multi-linear regression, assuming a $5 \%$ probability level. Stepwise regression fits variables in the order of their importance, thereby providing an indication of the contribution of each of the individual input variables. If a variable does not significantly reduce the variance between the data and fit, it is dropped. This permits users to determine the main variables that influence their data. This approach is especially useful when developing models that have a large number of independent variables and it is unclear which ones should be included as input variables (e.g., Afifi \& Aizen 1979, StatSoft Inc. 1995, Statistical Graphics Corp. 1999).

\section{RESULTS AND DISCUSSION}

\subsection{Climate variability}

The long-term variation of air temperature was investigated for all 9 climatological divisions in Georgia. The results were also averaged for the entire state. The variation in maximum air temperature during the first 3 decades of the 20th century was very similar to the current climatic conditions, which are based on the period 1961-1990, according to the recommendations of the World Meteorological Organization (WMO). Annual minimum air temperature during the first 3 decades of the 20th century was between 0.5 and $2.0^{\circ} \mathrm{C}$ higher than for 1961-1990. The period during the 1930s, 1940s and the first half of the 1950s could be characterized as a warm period, taking into account the positive anomalies both in maximum and minimum air temperatures. In contrast, a cool period was observed in the 1960s. Since then, the annual maximum air temperature has varied slightly around the values of the current climate, except during the last 5 yr of the investigation, when the annual maximum air temperature was below normal. However, an increase in annual minimum air temperature was observed since

Table 1. Classification of El Niño events using annual, 6 and 3 mo SOI averages with a -0.8 threshold

\begin{tabular}{|c|c|c|c|c|c|c|c|c|c|c|c|c|c|c|}
\hline \multirow{2}{*}{$\begin{array}{l}\text { Period } \\
\text { Annual }\end{array}$} & \multicolumn{14}{|c|}{ Year } \\
\hline & $\begin{array}{l}1905 \\
1993\end{array}$ & $\begin{array}{l}1912 \\
1994\end{array}$ & $\begin{array}{l}1914 \\
1997\end{array}$ & 1919 & 1940 & 1941 & 1956 & 1972 & 1977 & 1982 & 1983 & 1987 & 1991 & 1992 \\
\hline April-September & $\begin{array}{l}1905 \\
1982\end{array}$ & $\begin{array}{l}1911 \\
1987\end{array}$ & $\begin{array}{l}1912 \\
1991\end{array}$ & $\begin{array}{l}1914 \\
1993\end{array}$ & $\begin{array}{l}1919 \\
1994\end{array}$ & $\begin{array}{l}1932 \\
1997\end{array}$ & 1940 & 1941 & 1946 & 1951 & 1953 & 1965 & 1972 & 1977 \\
\hline October-March ${ }^{\mathrm{a}}$ & $\begin{array}{l}1905 \\
1987\end{array}$ & $\begin{array}{l}1906 \\
1992\end{array}$ & $\begin{array}{l}1912 \\
1993\end{array}$ & 1915 & 1919 & 1926 & 1940 & 1941 & 1942 & 1952 & 1966 & 1973 & 1978 & 1983 \\
\hline October-December & $\begin{array}{l}1901 \\
1986\end{array}$ & $\begin{array}{l}1905 \\
1991\end{array}$ & $\begin{array}{l}1913 \\
1992\end{array}$ & $\begin{array}{l}1919 \\
1994\end{array}$ & $\begin{array}{l}1925 \\
1997\end{array}$ & 1939 & 1940 & 1941 & 1951 & 1963 & 1965 & 1972 & 1977 & 1982 \\
\hline January-March & $\begin{array}{l}1905 \\
1993\end{array}$ & 1912 & 1915 & 1919 & 1926 & 1941 & 1942 & 1958 & 1966 & 1970 & 1978 & 1983 & 1987 & 1992 \\
\hline
\end{tabular}




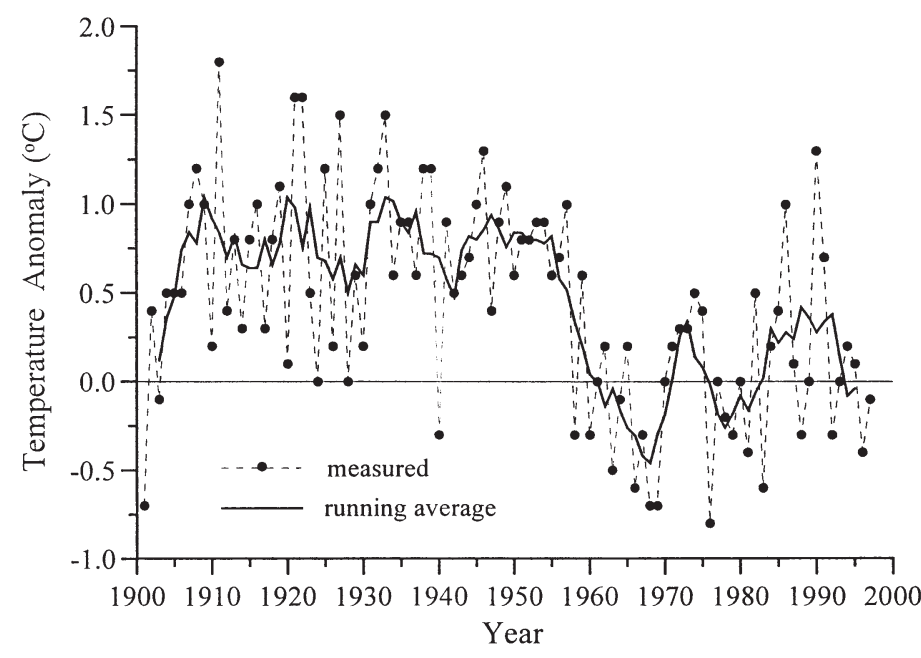

Fig. 2. Anomalies of annual mean air temperature in Georgia, relative to the period 1961-1990
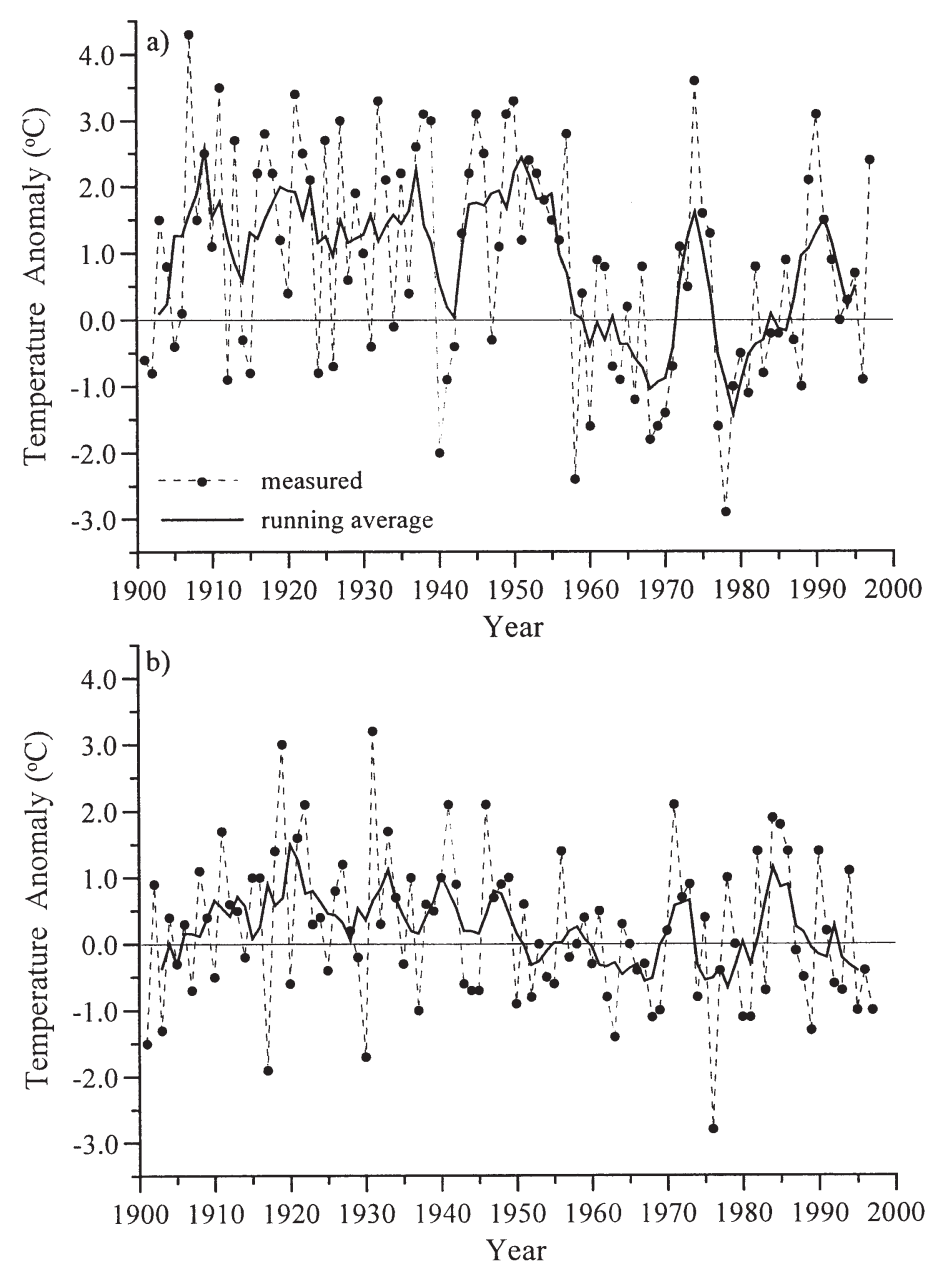

Fig. 3. Anomalies of mean air temperature in Georgia during (a) winter (January-March) and (b) autumn (OctoberDecember), relative to the period 1961-1990 the end of the 1960s. As a result of the variation in maximum and minimum air temperatures, annual mean air temperature had a statistically significant decreasing trend during the study period (Fig. 2). This trend was opposite in comparison to the trend of the global mean surface air temperature, which has increased by 0.3 to $0.6^{\circ} \mathrm{C}$ since the late 19 th century (e.g., Houghton 1996).

Annual air temperatures in Georgia in 1996 and 1997 were lower than the normal climatic conditions (1961-1990). The variations of mean air temperature were relatively similar in all climatological divisions in Georgia, except the ones in the northeast mountain division, where mean air temperature in the 1930s was below or near to its normal (1961-1990) values. The anomalies of annual mean temperature were higher in the northwest climatological division and lower in southeast Georgia.

Mean air temperature in Georgia from April to September and from October to March was higher during the first half of the century, relative to the normal climatic conditions. This caused a negative trend of air temperature during the warm and cold halves of the year for the studied period (1901-1997) which was statistically significant. Similar variations and statistically significant trends were obtained for the winter (January-March), spring (April-June) and summer (July-September) seasons. Cooler spells during the winter were observed at the end of the 1960s and 1970s (Fig. 3a). The anomalies in January 1977 and February 1978 were near -5 and $-4^{\circ} \mathrm{C}$, respectively. The decrease in mean air temperature was monotonous and statistically significant for spring, but it was not significant for autumn (October-December) (Fig. 3b). The increase in mean temperature during the summer season which has been observed since the 1960s was mainly caused by an increase in mean air temperature in July, the warmest month of the year in Georgia.

Annual precipitation in Georgia showed significant annual variation. Georgia has experienced several drought episodes during the 20th century, most notably in the 1930s, 1950s and 1980s (Fig. 4a). Drought periods in the 1930s and 1980s were more significant in north Georgia. However, the drought spell in the 1950s occurred across the entire state. Drought was most severe in 1954 in central and south Georgia, with precipitation less than $35 \%$ of the normal (1961-1990) climatic values. In general, the variation in mean annual precipitation in Georgia did not show a statistically significant trend. A slight increase in annual precipitation has been observed in the east central climatological division since the 1930s.

The filtered curve in Fig. 4b suggests that there has been a decrease in precipitation from April to Septem- 
ber, starting at the end of the 1970s. Precipitation has been below the $30 \mathrm{yr}(1961-1990)$ average for 13 of the last 21 yr. The years 1986, 1990 and 1993 are among the driest warm-half years. In the 1980s a drought occurred in all climatological divisions, while a reduction in precipitation in the 1950s was only observed in north Georgia. Precipitation during the cold-half of the year (October-March) has statistically significantly increased since the 1950s (Fig. 4c). It is especially dominant in the east-central, south-central and southeast climatological divisions. Precipitation anomalies in the south-central division have been above normal during the last $7 \mathrm{yr}$ of this study.

Precipitation during the winter months (from January to March) varied without any significant trend in north Georgia. However, precipitation in central and south Georgia showed an increase. Especially since the beginning of the 1950s, precipitation in south Georgia has increased. The drought spell during spring in the middle 1910s was followed by a 6 yr wet period. A long drought period similar to the ones during the springs of the 1980s and 1990s has not been observed in other years during the entire 20th century. The reduction in precipitation for April and May during the last 2 decades has, in most cases, been higher than $40 \%$ across the entire state. Although there is an increase in precipitation during the summer from the beginning of the 1980s, overall summer precipitation shows a statistically significant decrease for 1901 to 1997. Precipitation in July in southeast Georgia has decreased since the 1960s. However, precipitation anomalies were mainly positive in the north-central, northeast and central climatological divisions of Georgia during the 1990s. The autumn seasonal precipitation, e.g., from October to December, showed a statistically significant increasing trend across Georgia from the middle of the 1950s, due to precipitation increases during the October and November months. Precipitation during December varied both above and below current climatic normals.

Most El Niño episodes during the cold-half of the year have featured an increased frequency of precipitation occurrence above normal. Only 5 out of all 17 El Niño events, classified for the same period (from October to March), were characterized with negative precipitation anomalies, e.g., in 1905, 1915, 1940, 1941 and 1992 (Fig. 4c, Table 1). In general, the El Niño conditions during the autumn season (October-December) were related to precipitation quantities higher than the normal for the entire state. The highest positive precipitation anomalies, relative to the period 1961-1990, occurred in $1925(64 \%), 1986$ $(44 \%), 1992(53 \%), 1994(47 \%)$ and especially 1997 (78\%). The 1997-1998 El Niño episode started in the spring of 1997 and produced a very strong signal.
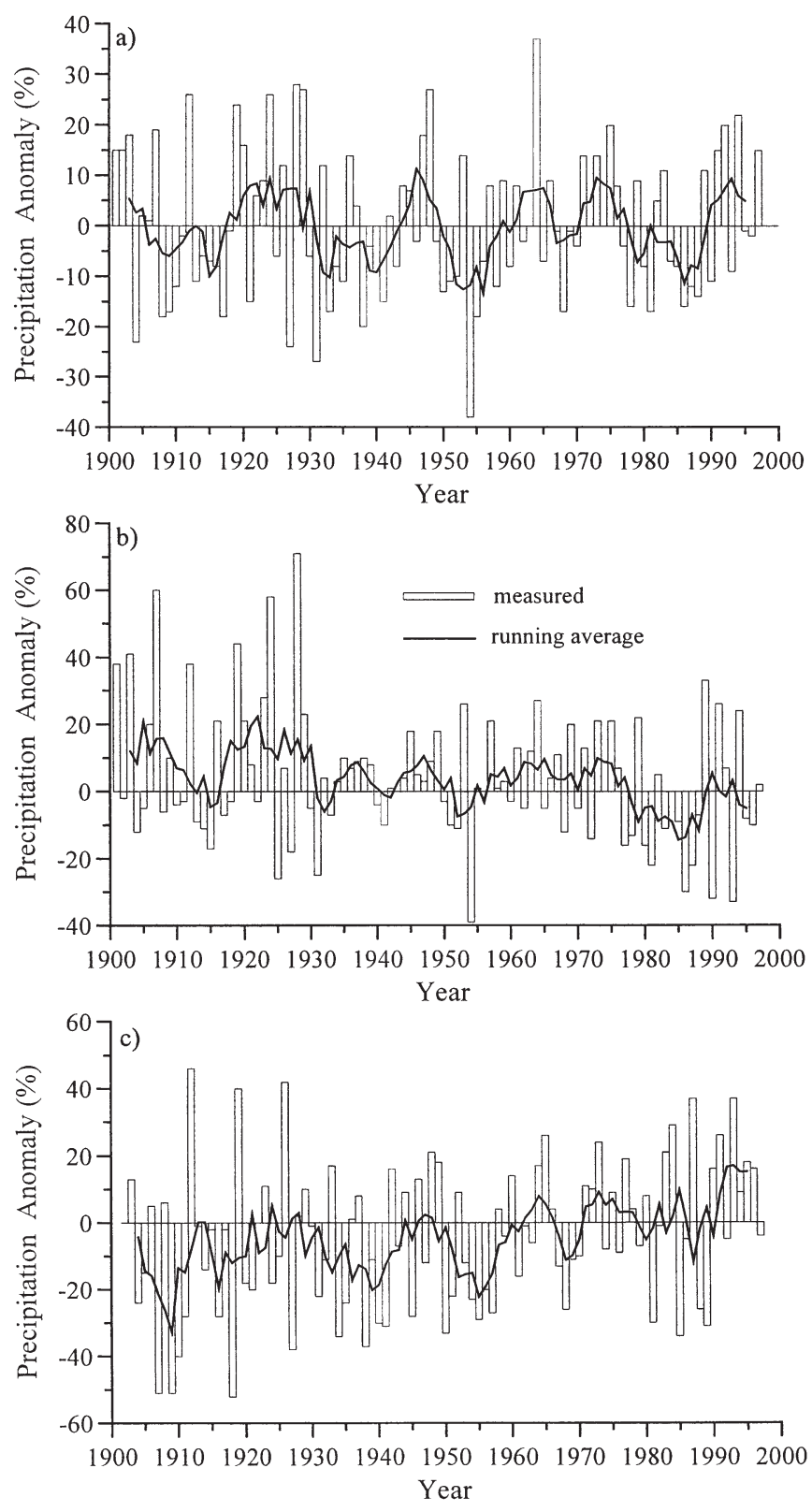

Fig. 4. Anomalies of precipitation in Georgia for the complete year (a), and during the warm (b: April-September) and cold (c: October-March) halves of the year, relative to the period 1961-1990

Therefore, both the warm-half of the year as well as the entire year were classified as El Niño events. During the other strong El Niño episode in 1982-1983, most of the climatological divisions in Georgia experienced above normal precipitation: more than $20 \%$ above normal precipitation during the cold-half of the year, e.g., October-March. During the autumn El Niño events, the state has tended to be warmer than the normal climatic conditions, taking into account 

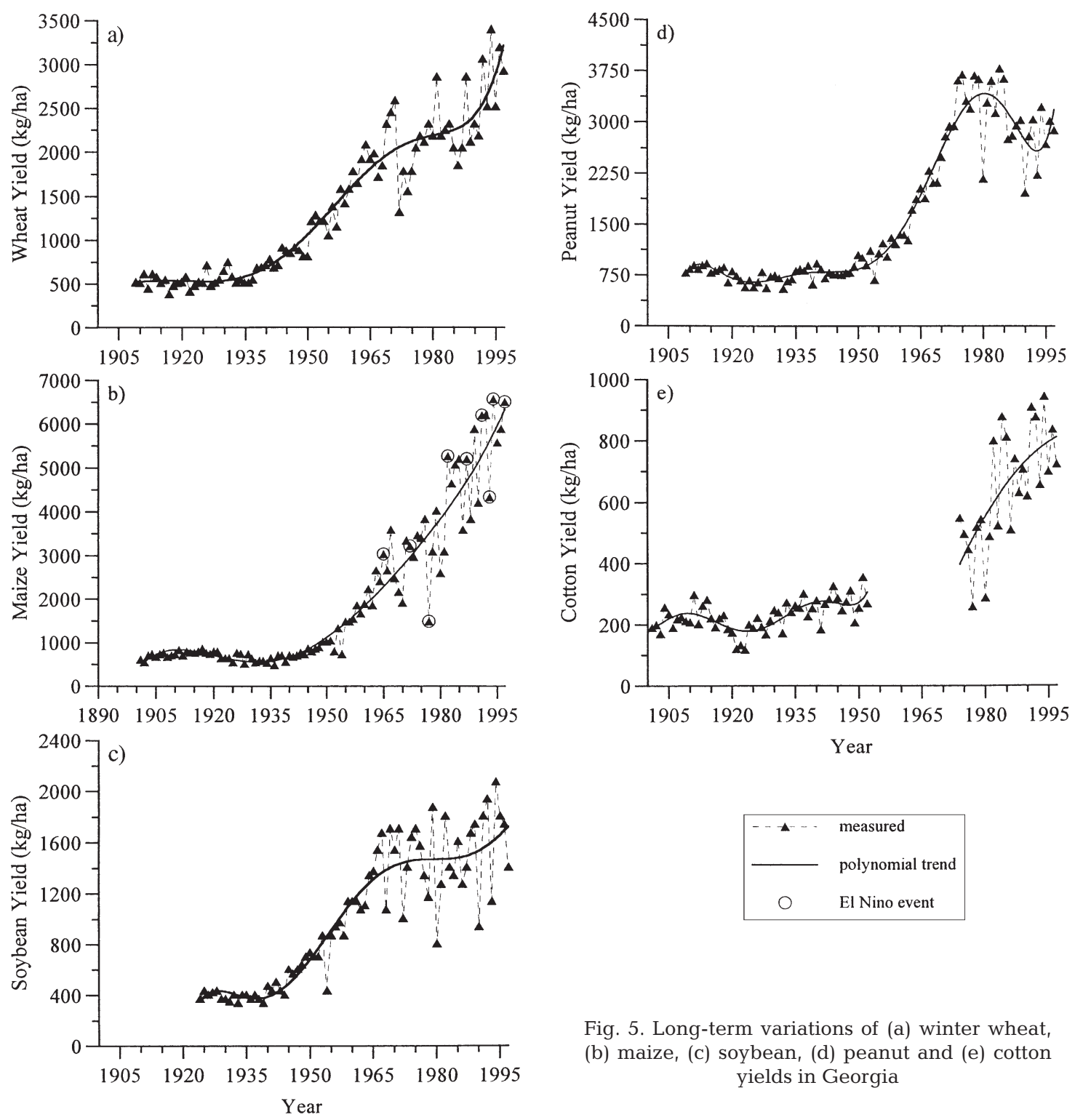

that the mean air temperature anomalies were positive for 12 of the 19 El Niño episodes. However, almost all classified winter El Niños were followed by a lower mean air temperature from January to March. For example, the mean air temperature anomaly during the winter was $-2.4^{\circ} \mathrm{C}$ in 1958 and $-2.9^{\circ} \mathrm{C}$ in 1978 (Fig. 3, Table 1).

\subsection{Crop yield variability}

Long-term variations of mean winter wheat, maize, soybean, peanut, and cotton yields in Georgia are presented in Fig. 5. Yield for all crops varied from year to year during the study period. However, the yield

variations are more significant after the mid-century. Since the 1950s, the mean crop yield in Georgia has increased considerably due to utilization of technological innovations and improved agrotechnological crop management in agriculture.

Current (1961-1990) precipitation during the coldhalf of the year (October-March) ranged from 500 to $560 \mathrm{~mm}$ in east and southeast Georgia, 560 to $700 \mathrm{~mm}$ in central, west and south Georgia, and 700 to $900 \mathrm{~mm}$ in north Georgia. Precipitation during the spring season, e.g., April-June, varied between 280 and $380 \mathrm{~mm}$. It is normally assumed that the water requirements for winter wheat are met by the high values of precipitation during the growing season, especially between October and June. Therefore, winter wheat is normally 
grown as a rainfed crop in the region. However, winter wheat growth, development and final grain yield in Georgia are sensitive to air temperature. Higher air temperatures during the growing season sometimes lead to lower grain yield, while lower temperatures than the current climatic values seem to increase wheat yield (Fig. 5a, Table 2).

Precipitation during the warm-half of the year, e.g., April-September, is an important environmental factor during the growing season for spring crops, and it has a significant impact on potential crop yield. A deficit in precipitation is usually the most important constraint, limiting crop production. Precipitation from April to September is $580 \mathrm{~mm}$ in Central Georgia and increases to 760-840 $\mathrm{mm}$ for either the northern or the southern part of the state. A precipitation deficit can lead to a potential reduction in yield during some

Table 2. Winter wheat yield and temperature anomalies $(\Delta T)$ for selected years

\begin{tabular}{|c|c|c|c|c|}
\hline \multirow[t]{2}{*}{ Year } & \multirow{2}{*}{\multicolumn{2}{|c|}{$\begin{array}{cr}\text { Yield } & \text { Yield } \\
\text { measured } & \text { trend } \\
\left(\mathrm{kg} \mathrm{ha}^{-1}\right)\end{array}$}} & \multicolumn{2}{|c|}{$\Delta T\left({ }^{\circ} \mathrm{C}\right)$} \\
\hline & & & Jan-Mar & Oct-Mar \\
\hline 1926 & 737 & 536 & -0.7 & -0.2 \\
\hline 1931 & 771 & 536 & -0.4 & -1.0 \\
\hline 1949 & 838 & 1039 & 3.1 & 2.0 \\
\hline 1950 & 838 & 1106 & 3.3 & 2.2 \\
\hline 1964 & 2111 & 1776 & -0.9 & -1.1 \\
\hline 1969 & 2345 & 1977 & -1.6 & -1.4 \\
\hline 1970 & 2479 & 2044 & -1.4 & -1.2 \\
\hline 1971 & 2613 & 2111 & -0.7 & -0.2 \\
\hline 1972 & 1340 & 2144 & 1.1 & 1.6 \\
\hline 1973 & 1809 & 2178 & 0.5 & 0.6 \\
\hline 1974 & 1575 & 2211 & 3.6 & 2.3 \\
\hline 1975 & 1809 & 2245 & 1.6 & 0.5 \\
\hline 1981 & 2881 & 2345 & -1.1 & -1.1 \\
\hline 1986 & 1876 & 2479 & 0.9 & 1.4 \\
\hline 1988 & 2881 & 2546 & -1.0 & -0.5 \\
\hline 1989 & 2114 & 2613 & 2.1 & 0.8 \\
\hline 1990 & 2345 & 2647 & 3.1 & 1.0 \\
\hline 1991 & 2211 & 2714 & 1.5 & 1.4 \\
\hline
\end{tabular}

Table 3. Precipitation $(\Delta P)$ and mean $(\Delta T)$ and maximum $\left(\Delta T_{\max }\right)$ air temperature anomalies for selected years

\begin{tabular}{|crrccc|}
\hline Year & Apr-Jun & $\begin{array}{c}\Delta P(\%) \\
\text { Jul-Sep }\end{array}$ & Apr-Sep & $\begin{array}{c}\Delta T\left({ }^{\circ} \mathrm{C}\right) \\
\text { Apr-Sep }\end{array}$ & $\begin{array}{c}\Delta T_{\max }\left({ }^{\circ} \mathrm{C}\right) \\
\text { Apr-Sep }\end{array}$ \\
\hline 1954 & -34 & -44 & -39 & 1.1 & 1.6 \\
1977 & -43 & 8 & -16 & 1.0 & 1.3 \\
1980 & -1 & -29 & -16 & 0.8 & 0.9 \\
1981 & -22 & -23 & -22 & 0.4 & 0.6 \\
1986 & -53 & -9 & -30 & 0.9 & 1.1 \\
1990 & -43 & -22 & -32 & 0.5 & 0.7 \\
1993 & -33 & -32 & -33 & 0.3 & 0.5 \\
\hline
\end{tabular}

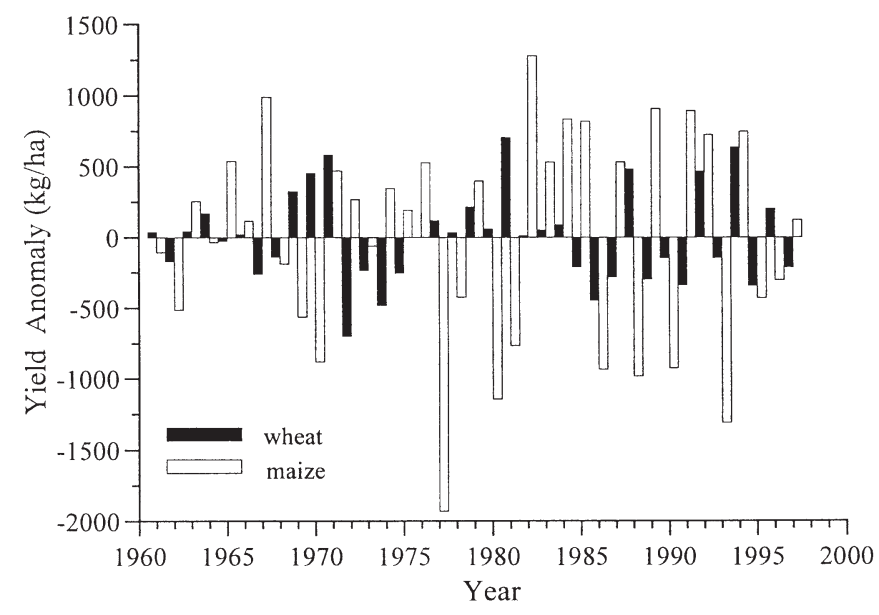

Fig. 6. Anomalies of detrended yield of winter wheat and maize during the period 1961-1997

years. Under both drought conditions and higher air temperatures final yield can decrease significantly. This situation occurred, for example, for maize in 1954, 1977, 1980, 1981, 1986, 1990 and 1993 (Figs. 4b \& 5b, Table 3). Similar combinations of reduced precipitation, higher air temperature and lower crop yield were observed in 1954, 1980, 1990 and 1993 for soybean and peanut, and in 1977, 1980, 1986, 1990 and 1993 for cotton (Figs. 4b \& 5c,d,e, Table 3).

An analysis was conducted to determine if a direct relation exists between El Niño events during the cold and warm halves of the year and yield of winter wheat, maize, soybean, peanut, and cotton from 1961 to 1997. Annual maize yield was, in most cases, above the polynomial trend (Fig. 5b). The El Niño conditions during the growing season of maize in 1977 and 1993 were characterized by drought, which caused a decrease in grain yield. It is important to note that normally every El Niño event is unique with respect to precipitation patterns and areas affected by possible dry conditions.

Agrotechnological trends in crop yield variations were removed for the last $37 \mathrm{yr}(1961-1997)$ of the study in order to develop quantitative relationships between detrended yield of winter wheat, maize, soybean, peanut, and cotton and precipitation and air temperature. In Fig. 6, anomalies of detrended grain yield of winter wheat and maize are presented.

Linear relationships between the detrended crop yield anomalies in Georgia and anomalies of meteorological variables such as air temperature and precipitation were developed, using stepwise multilinear regression (e.g., Afifi \& Aizen 1979, StatSoft Inc. 
1995, Statistical Graphics Corp. 1999). However, before using stepwise multilinear regression, a simple linear regression was applied to evaluate the correlation between the anomalies of yield, precipitation and air temperature. In general, anomalies of meteorological values with a relatively significant correlation to crop yield anomalies were used as input variables in the stepwise multilinear regression calculations. This was done in order to decrease to a relatively appropriate minimum the initial input variables in the stepwise multilinear regression model. For example, it was found that the correlation coefficient between the winter wheat yield anomalies and the mean air temperature anomalies during the cold-half of the year was equal to -0.65 . Therefore minimum air temperature anomalies were not used as input variables. It was assumed that minimum air temperature is not significant, especially for spring crops in Georgia. The same principle approach was applied to precipitation and winter wheat yield. Precipitation anomalies were rejected as an input variable in the stepwise multilinear regression calculations. Therefore, the only initial input variables were the anomalies of mean air temperature during the cold-half of the year and the monthly mean air temperature anomalies from October to May. This resulted in the following multiple relationship between the anomalies of mean winter wheat yield and air temperature:

$$
\Delta Y_{\mathrm{wh}}=-288.563 \Delta T_{\mathrm{Oct}-\mathrm{Mar}}+69.556 \Delta T_{\mathrm{Feb}}-82.237 \Delta T_{\mathrm{MaY}}
$$

where $\Delta Y_{\text {wh }}$ are anomalies of detrended mean winter wheat yield in Georgia; $\Delta T_{\text {Oct-Mar }}$ are anomalies of mean air temperature from October to March; and $\Delta T_{\mathrm{Feb}}$ and $\Delta T_{\mathrm{May}}$ are anomalies of mean air temperature in February and May. Higher air temperatures during the cold-half of the year affect final winter wheat yield considerably. Positive anomalies of air temperature in May also lead to a decrease in wheat yield due to a shorter grain filling period. Higher temperatures in February are beneficial to winter wheat due to an enhancement of early development, following the process of vernalization.

Similarly, statistical relations between anomalies of mean maize, soybean, peanut and cotton yield and precipitation and air temperature during the current climate conditions (1961-1997) were developed. It was found that the precipitation anomalies in July have the most significant impact on the yield anomalies for the spring crops used in the study. Maize is mainly affected by a precipitation deficit and high air temperatures, especially during the grain filling period; higher air temperatures cause a decrease in grain filling duration. For maize, therefore, the initial input variables into the stepwise multilinear regression model were the precipitation anomalies during the months from March to August and the anomalies of maximum air temperature for the same months.

Taking into account the growing season in Georgia for soybean, cotton and peanut as well as the climatic conditions, the anomalies of precipitation and maximum air temperatures for the months from May to September were used as model inputs. Due to a significant correlation obtained for peanut, the anomalies of the mean air temperatures for the warm-half of the year (April-September) and summer (July-September) were also used as initial input variables.

The multilinear regression analysis resulted in the following equations for the maize, soybean, peanut and cotton yield anomalies:

$$
\begin{aligned}
& \Delta Y_{\mathrm{mz}}=4.914 \Delta R_{\mathrm{Jun}}+11.306 \Delta R_{\mathrm{Jul}}-285.153 \Delta T_{\mathrm{Jun}}^{\max } \\
& \Delta Y_{\mathrm{sb}}=1.963 \Delta R_{\mathrm{Jul}}+2.974 \Delta R_{\mathrm{Aug}}-140.670 \Delta T_{\mathrm{Sep}}^{\max } \\
& \Delta Y_{\mathrm{pn}}=3.412 \Delta R_{\mathrm{Jul}}-235.606 \Delta T_{\mathrm{Jul}-\mathrm{Sep}} \\
& \Delta Y_{\mathrm{co}}=1.804 \Delta R_{\mathrm{Jul}}-1.599 \Delta R_{\mathrm{Sep}}-54.831 \Delta T_{\mathrm{Sep}}^{\max }
\end{aligned}
$$

where $\Delta Y_{\mathrm{mz}}, \Delta Y_{\mathrm{sb}}, \Delta Y_{\mathrm{pn}}$ and $\Delta Y_{\mathrm{co}}$ are anomalies of detrended mean maize, soybean, peanut and cotton yield in Georgia; $\Delta R_{\mathrm{Jul}}, \Delta R_{\mathrm{Aug}}$ and $\Delta R_{\text {Sep }}$ are anomalies of precipitation in July, August and September; $\Delta T_{\mathrm{Jun}}^{\max }$ and $\Delta T_{\mathrm{Sep}}^{\max }$ are anomalies of maximum air temperature in June and September; and $\Delta T_{\mathrm{Jul}-\mathrm{Sep}}$ is the anomaly of mean air temperature in summer (July-September). All statistical models for the spring crops include precipitation during the warmest month of the year, July. Precipitation in August is an important factor that can increase yield potential for soybean, taking into account that soybean is harvested in November. Precipitation in September affects cotton yield. Higher air temperatures decrease yield for all spring crops. Mean air temperature during the summer season affects peanut yield (Eq. 4). A higher maximum air temperature in June has a negative impact on maize yield. The increase of maximum air temperature in September affects soybean and cotton yield, respectively. It is important to note that the statistical relation for cotton (Eq. 5) was developed using data for a shorter period, 1974-1997, due to the lack of yield data between 1952 and 1973. Nevertheless, the coefficient of determination $\left(\mathrm{r}^{2}\right)$ for cotton (Eq. 5) shows satisfactory results (Table 4). A comparison between observed and simulated yield anomalies for winter wheat, maize, soybean, peanut, and cotton is presented in Fig. 7. Simulated crop yield anomalies were in most cases in accordance with the observed yield anomalies, with $\mathrm{r}^{2}$ ranging from 0.52 to 0.77 . All results are statistically significant at a $5 \%$ probability level (Table 4). 
Table 4. Statistical characteristics of the developed multilinear crop-weather models. $\mathrm{r}^{2}$ : coefficient of determination; df: degrees of freedom of the initial multilinear models; RMSE: root mean square error; DurbWat: Durbin-Watson statistic

\begin{tabular}{|lccccc|}
\hline Model - Crop & Degree of significance & $\mathrm{r}^{2}$ & df & RMSE & DurbWat \\
\hline 1 - Wheat & 0.05 & 0.60 & 28 & 213.1 & 2.09 \\
2 - Maize & 0.05 & 0.73 & 25 & 421.5 & 1.52 \\
3 - Soybean & 0.05 & 0.76 & 27 & 154.9 & 1.71 \\
- Peanut & 0.05 & 0.52 & 25 & 232.1 & 1.40 \\
- Cotton & 0.05 & 0.77 & 14 & 70.1 & 2.23 \\
\hline
\end{tabular}

\section{CONCLUSIONS}

Annual air temperature for the 20th century showed a statistically significant negative trend in Georgia. This is opposite to the trends of the national and global mean surface air temperature, which have shown a slight increase. This confirms that the local or state climate can have a different variability or trend, compared to regional, national and especially global climate variability and trends. Precipitation in Georgia showed a considerable annual variation from 1901 to 1997. Georgia has experienced several drought episodes during the 20th century, especially in the 1930s, 1950s and 1980s. A decrease in precipitation from April to September was found from the end of 1970s. It is difficult to predict precipitation variations during the 21st century. However, the drought occurrences in 1998, 1999, and 2000 have persisted for a long time, prompting one to ask if a precipitation deficit is becoming more frequent or extensive. Most El Niño episodes during the cold-half of the year, October-March, have featured an increased frequency of occurrence of above current precipitation in Georgia. During the autumn El Niño events, the state has tended to be warmer than the current climatic condition. However, almost all classified winter El Niños were followed by a lower mean air temperature from January to March.

The outcomes of this study can be used by researchers to assess current climatic fluctuations and variability and the expected climate change for the 21 st century. Some of these results can even be helpful for different consumer groups. Several climatological maps, representing annual, seasonal, and monthly precipitation, as well as maximum, minimum, and mean air temperature have therefore been created, using the averages from the 85 weather stations for the period 1961-1990. They are presented as part of the Georgia Automated Environmental Monitoring Network (GAEMN) home page at http://www. georgiaweather.net and are available to the general public. Deviations from normal, i.e., 1961-1990, for precipitation and temperature are also displayed on the Web.
In general, air temperature and precipitation are the major weather factors that determine the variability of crop production in Georgia. A higher air temperature during the cold-half of the year normally results in a lower grain yield for wheat, while lower temperatures sometimes can increase wheat yield. All crops, including maize, soybean, peanut, and cotton, are affected by a higher air temperature as well as a precipitation deficit during the warm-half of the year. Especially a low amount of precipitation during July, the warmest month of the year, affects all major crops. Since 1961, maize yield has been higher in years with El Niño events during the warm-half of the year. A detailed study regarding the impact of El Niño on agriculture in Georgia is recommended. The proposed statistical linear models that describe the relationship between crop yield, precipitation, and air temperature can be used to assess expected anomalies of mean winter wheat, maize, soybean, peanut, and cotton yields before harvest maturity is reached in a particular year. However, a verification of these models on independent yield and weather data should be conducted. In addition to stepwise multilinear regression, principal component regression and partial least square regression are also recommended in further studies. This approach can

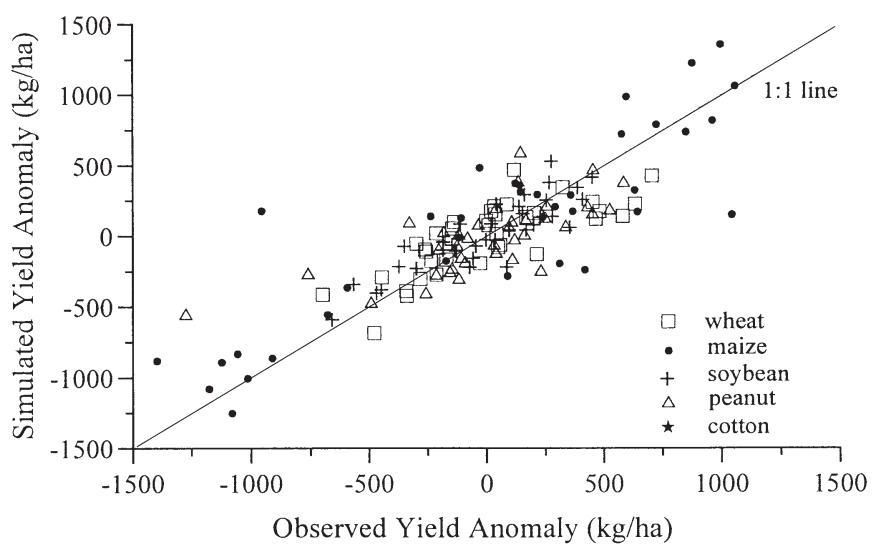

Fig. 7. Comparison between observed and simulated yield anomalies of winter wheat, maize, soybean, peanut and cotton during the period 1961-1997 
especially be useful when the dependent series are short and there are many possible independent variables. Some of the results obtained in this study can also be used in the ongoing US national assessment of the potential consequences of climate variability and change on agricultural production and natural resources.

Acknowledgements. This work was partially supported by a grant from the National Science Foundation/North Atlantic Treaty Organization and State and Federal Funds allocated to Georgia Agricultural Experiment Stations Hatch Project GEO01513.

\section{LITERATURE CITED}

Afifi A, Aizen S (1979) Statistical analysis: a computer oriented approach. Academic Press, New York

Allan RJ, Nicholls N, Jones PD, Butterworth IJ (1991) A further extension of the Tahiti-Darwin SOI, early SOI results and Darwin pressure. J Clim 4:743-749

Carlson RE, Todey DP, Taylor SE (1996) Midwestern corn yield and weather in relation to extremes of the Southern Oscillation. J Prod Agric 9:347-352

Cayan DR, Dettinger MD, Diaz HF, Graham NE (1998) Decadal variability of precipitation over Western North America. J Clim 11(12):3148-3166

CRU (Climate Research Unit) (1999) Southern Oscillation Index (SOI). CRU, Norwich (accessed: March 14, 2001); available at http://www.cru.uea.ac.uk/cru/data

Decker W, Achutuni R (1988) The use of statistical climatecrop models for simulating yield to project the impacts of $\mathrm{CO}_{2}$ induced climate change. Cooperative Institute for Applied Meteorology, College of Agriculture, University of Missouri-Columbia, Columbia, MO

EarthInfo Inc. (1997) Database guide for EarthInfo CD NCDC summary of the day. Earth Info Inc, Boulder, CO

Easterling DR (1999) Variations and trends in extreme temperature events in the USA. In: Preprints of the 11th Conference on Applied Climatology, Dallas, TX. American Society of Meteorology, Boston, MA, p 201

Freckleton RP, Watkinson AR, Webb DJ, Thomas TH (1999) Yield of sugar beet in relation to weather and nutrients. Agric For Meteorol 93(1):39-51

Gadgil S, Rao PRS, Sridhar S (1999) Modeling impact of climate variability on rainfed groundnut. Curr Sci 76(4): 557-569

Hansen JW, Jones JW (1999) ENSO impacts on crop production in the Southeast US. Agronomy abstracts. American Society of Agronomy, Madison, WI

Hansen JW, Hodges AW, Jones JW (1998a) ENSO influences on agriculture in the Southeastern United States. J Clim 11:404-411

Hansen JW, Irmak A, Jones JW (1998b) El Niño-Southern Oscillation influences on Florida crop yields. Soil Crop Sci Soc Fla Proc 57

Hansen JW, Jones JW, Kiker CF, Hodges AW (1998c) El NiñoSouthern Oscillation impacts on winter vegetable production in Florida. J Clim 12:92-101

Henderson KG, Muller RA (1997) Extreme temperature days in the South Central United States. Clim Res 8(2):151-162

Houghton J, Meira Filho L, Callander B, Harris N, Kattenberg A, Maskell K (eds) (1996) Climate change 1995-the science of climate change. Contribution of WG I to the sec- ond assessment report of the IPCC. Cambridge University Press, Cambridge

Karl TR, Knight RW, Easterling DR, Quayle RQ (1995a) Trends in U.S. climate during the twentieth century. Consequences 1(1):1-9

Karl TR, Knight RW, Easterling DR, Quayle RQ (1995b) Indices of climate change for the United States. Bull Am Meteorol Soc 77(2):279-292

Karl TR, Knight RW, Plummer N (1995c) Trends in high frequency climate variability in the 20th century. Nature 377(6546):217-220

Katz R (1979) Sensitivity analysis of statistical crop weather models. Agric Meteorol 20:291-300

Kaufmann RK, Snell SE (1997) A biophysical model of corn yield: integrating climatic and social determinants. Am J Agric Econ 79:178-190

Kiladis GN, van Loon H (1988) The Southern Oscillation. Part VII: Meteorological anomalies over Indian and Pacific sectors associated with the extremes of the oscilations. Mon Weather Rev 116:120-136

Können GP, Jones PD, Kaktofen MH, Allan RJ (1998) Pre1866 extensions of the Southern Oscillation Index using early Indonesian and Tahitian meteorological readings. J Clim 11(9):2325-2329

Mauget SA, Upchurch DR (1999) ENSO related climate and agricultural impacts over the Great Plains and Midwest. In: Preprints of the 11th Conference on Applied Climatology, Dallas, TX. American Society of Meteorology, Boston, MA, p 82-85

Michaels PJ, Balling RC, Vose RS, Knappenberger PC (1998) Analysis of trends in the variability of daily and monthly historical temperature measurements. Clim Res 10(1): $27-33$

NASS (National Agricultural Statistics Service) (1999) http://www.nass.usda.gov/ipedb/ (accessed March 14, 2001)

NCDC (National Climatic Data Center) (1999) Climate variations bulletin. Hist Climatol Ser 4-7 11(2):1-20

Perkey DJ, Hayes CE (1998) Alabama corn and cotton production and its relation to precipitation. In: Proceedings of the 23rd Conference on Agricultural and Forest Meteorology, Albuquerque, NM. American Society of Meteorology, Boston, MA, p 90-93

Philips JG, Cane MA, Rosenzweig C (1998) ENSO, seasonal rainfall patterns and simulated maize yield variability in Zimbabwe. Agric For Meteorol 90:39-50

Portman DA, Gutzler DS (1996) Explosive volcanic eruptions, the El-Niño Southern Oscillation and US climate variability. J Clim 9(1):17-33

Ropelewski CF, Jones PD (1987) An extension of the TahitiDarwin Southern Oscillation Index. Mon Weather Rev 115:2161-2165

Rotter RP, van Diepen CA, van der Wal T (1998) Relations between climate variability and crop yield variability in the Rhie Area, In: Dalezios NR (ed) International Symposium on Applied Agrometeorology and Agroclimatology, COST 77, 79, 711, Proceedings, Volos, Greece, 24 to 26 April 1996. European Community, Luxembourg, p 45-52

Singels A, Potgieter AB (1997) A technique to evaluate ENSO-based maize production strategies. S Afr J Plant Soil 14(3):93-97

Skaggs RH, Baker DG, Ruschy DL (1995) Interannual variability characteristics of the Eastern Minnesota (USA) temperature record-implication for climate change studies. Clim Res 5(3):223-227

Smith JW (1914) The effect of weather upon the yield of corn. Mon Weather Rev 42:78-93 
Solow AR, Adams RF, Bryant KJ, Legler DM, Brien JJ, McCarl BA, Nayda W, Weiher R (1998) The value of improved ENSO prediction to U.S. agriculture. Clim Change 39: $47-60$

Stahle DW, Cleaveland MK (1994) Tree-ring reconstructed rainfall over the Southeastern USA during the medieval warm period and little ice era. Clim Change 26(2-3): $199-212$

Statistical Graphics Corp. (1999) STATGRAPHICS Plus for Windows 4.0. User's guide. Manugistics, Inc, Rockville, MD

StatSoft Inc. (1995) STATISTICA for Windows. Computer program manual. StatSoft, Inc, Tulsa, OK

Stooksbury DE, Michaels PJ (1994) Climate change and large area corn yield in the Southeastern United States. Agron J 86(3):564-569

Thompson LM (1986) Climatic change, weather variability and corn production. Agron J 78:649-653

Editorial responsibility: Lawrence Kalkstein,

Newark, Delaware, USA
Thompson LM (1988) Effects of changes in climate and weather variability on the yields of corn and soybean. J Prod Agric 1:20-27

Todey DP, Carlson RE, Taylor SE (1999) ENSO and soil moisture effects on corn yields in the Midwest. In: Preprints of the 11th Conference on Applied Climatology, Dallas, TX. American Society of Meteorology, Boston, MA, p 86-88

Trenberth KE (1997) The Definition of El Niño. Bull Am Meteorol Soc 78(12):2771-2777

WMO (World Meteorological Organization) (1966) Climatic Change. Tech Note No. 79, publ no. 195, WMO, Geneva

WMO (1990) On the statistical analysis of series of observations. Tech Note No. 143, publ no. 415, WMO, Geneva

WMO (1994) Climate variability, agriculture and forestry. Tech Note No. 196, publ no. 802, WMO, Geneva

Woodhouse CA (1997) Winter climate and atmospheric circulation patterns in the Sonoran desert region, USA. Int J Climatol 17(8):859-873

Submitted: July 26, 1999; Accepted: November 14, 2000 Proofs received from author(s): March 15, 2001 